\title{
INCREASING THE BASELOAD CAPACITY OF BIOWASTE FERMENTATION PLANTS THROUGH OPTIMISED SUBSTRATE MANAGEMENT
}

\author{
Jan Sprafke ${ }^{1, \star}$, Nils Engler ${ }^{1}$, Qahtan Thabit ${ }^{1}$, Michael Nelles ${ }^{1,2}$ and Andrea Schüch ${ }^{1}$ \\ ${ }^{1}$ Faculty of Agricultural and Environmental Sciences, Department Waste and Resource Management, University of Rostock, D-18059 \\ Rostock, Germany \\ ${ }^{2}$ Deutsches Biomasseforschungszentrum gGmbH, D-04347 Leipzig, Germany
}

Article Info:
Received:
15 July 2019
Revised:
2 December 2019
Accepted:
18 December 2019
Available online:
11 February 2020
Keywords:
Biowaste
Green waste
Substrate management
Bioenergy
Biogas

\section{INTRODUCTION}

Biomass is the most diverse of all renewable forms of energy and replaces fuels of fossil origin all over the world. Biomass is available in solid, liquid or gaseous form and can be available as an energy source to generate all kinds of energy, for example electricity and thermal energy. In Germany, the use of biomass, and especially biogas from the fermentation of biomass, plays a major role as a result of support programmes by the federal government. German bioenergy technology and knowledge has played a key role in the use and implementation of biogas projects all over the world in recent years. Compared with other countries, the use of bioenergy has been strongly associated with the use of energy crops in the past. Changes in the legal framework have however resulted in a widespread stagnation in the construction of new fermentation plants in Germany. Plant expansions, the switch to flexible operation, the construction of small-scale liquid manure plants and the use of bionic waste and residues are mainly responsible for the current increase in installed capacity. Because the temporary subsidy for the electrical energy fed will end after 20 years, many plants are likely to stop operating in the future. Today, new construction plants can only be operated economically in operating modes with waste from three different origins. Practically all low-structure organic wastes are suitable for fermentation (ATV-DVWK, 2003). The quantity of separately collected biowaste in Germany has more than doubled, from $6,554,100 \mathrm{t}$ in 1996 to $15,612,800 \mathrm{t}$ in 2016 (Statistisches Bundesamt, 2019).

The anaerobic digestion of organic matter is an established alternative to aerobic waste treatment by compo- 
sting. In Germany first comments relating to the collection and treatment of biowaste and the associated biological treatment could be found in the 1993 TA Siedlungsabfall (Technical Directive for Municipal Waste) (Bundesamt für Justiz, 1993). Since 1 January 2015, the comprehensive collection of biowaste has been required for German municipalities in accordance with § 11 of the Kreislaufwirtschaftsgesetz (Closed Cycle Management Act) (Bundesamt für Justiz, 2012).

The yearly in Germany collected $15,612,800$ tonnes are treated aerobically or anaerobically in 1,256 biological treatment plants (Statistisches Bundesamt, 2019). The greatest advantage of anaerobic treatment compared to composting is the additional energy yield from the technical use of biogases. Central issues that need to be addressed in this field are the production of a constant biogas flow and establishing a stable fermentation process.

To promote the preferred feeding of electricity from renewable sources into the electricity grid, the Erneuerbare-Energien-Gesetz (Renewable Energy Sources Act) has been introduced in Germany. This law guarantees electricity producers a fixed feed-in tariff under specified conditions. In order to achieve the maximum fee of $€ 0.1488$ / $\mathrm{kWh}$, a minimum of $90 \%$ of anaerobically treated biowaste in a digestion plant must comply with the list of waste ordinance 200201 (biodegradable waste), 200301 (mixed municipal waste) and 200302 (market waste) (Bundesamt für Justiz, 2014). The remaining 10 percent comprises the so-called co-substrates. These come from agriculture, animal husbandry, industrial processing or trade and services. Figure 1 shows the relationships between the production sectors of suitable substrates.

In the German energy system, various performance classes can be found. For example, there are bioenergy plants with electrical outputs of less than 5 kilowatts and large industrial plant complexes with outputs in the twodigit megawatt class. Different criteria are used to differentiate the used technologies of anaerobic digestion. The following criteria are suitable for classifying the different variants:

1. Dry matter content of the substrate
a. Wet fermentation

b. Dry fermentation

2. Feeding of the plant
a. Discontinuously
b. Semi-continuously
c. Continuously

3. Process stages

a. Single-stage

b. Multi-stage

4. Process temperature
a. Psychrophile
b. Mesophile
c. Thermophile

The definition between wet and dry fermentation is not specified according to a specific level of dry matter content because the dry matter is strongly influenced by the substrate. To simplify, it can be said that pumpable substrates are used in wet fermentation and stackable substrates in dry fermentation.Fermentation plants for renewable resources and stock-farming products and residues often work according to the principle of wet fermentation.

The continuous feeding is characterised by multiple feeding of substrate batches into the fermenter during the day. Advantages result from the continuous gas production with constant substrate properties. Quasi-continuous processes are characterised by at least one addition of substrate per day. However, gas production in this process variant is more volatile than in continuous feeding processes. Discontinuous feeding is the characteristic parameter of batch processes. The digester is loaded with new substrate and inoculated with microorganisms by digested substrate. The batch process is characterised by a time-dependent gas production rate. State of the art is the operation with several batch fermenters to produce a continuous biogas flow.

The microorganisms in the fermenter have different specific process conditions such as temperature, $\mathrm{pH}$ value and temperature. In the technological implementation of fermentation, the subdivision into hydrolysis phase and methane phase has established as a preferred option. The stages describe the number of process tanks independent of the process phase. If the hydrolysis and methane phases proceed simultaneously in one process tank, this is called single-stage. In the case of constructional separation of the phases, the process is named multi-stage.

The different bacteria in the fermenter have different temperature optima at which they have a high reaction speed. During fermentation, a distinction is normally made between three temperature ranges: psychrophilic, mesophilic and thermophilic. Only mesophilic $\left(37-42^{\circ} \mathrm{C}\right)$ and thermophilic $\left(50-57^{\circ} \mathrm{C}\right)$ fermentation is of importance in practical applications. If substrates are to be hygenised and germs killed during the fermentation process, thermophilic fermentation is a suitable method. Some biowastes and co-substrates must comply with hygienic standards before spreading to the fields. According to the Bioabfallverordnung (Bio-waste Ordinance), hygienisation can be achieved by thermophilic treatment at temperatures above $50^{\circ} \mathrm{C}$ during the manufacturer-specific minimum residence time in the fermenter (Bundesamt für Justiz, 1998). However, the thermophilic version is more susceptible to process problems and requires more energy to heat the fermenter. Because of these substrate-specific properties, biowaste, green waste and waste from households is mainly fermented at thermophilic conditions.

The aim of this paper is to analyse data from an existing biowaste fermentation plant to find out the percentage of green waste in biowaste for each month over an observation period of three years. The second objective is to determine the influence of the proportion of green waste in biowaste on the biogas yield.

\subsection{List of abbreviations}

\author{
BG: Biogas \\ OS: Original substrate as fresh matter \\ IN: Inhabitant \\ CS: Co-substrate \\ BW: Biowaste
}




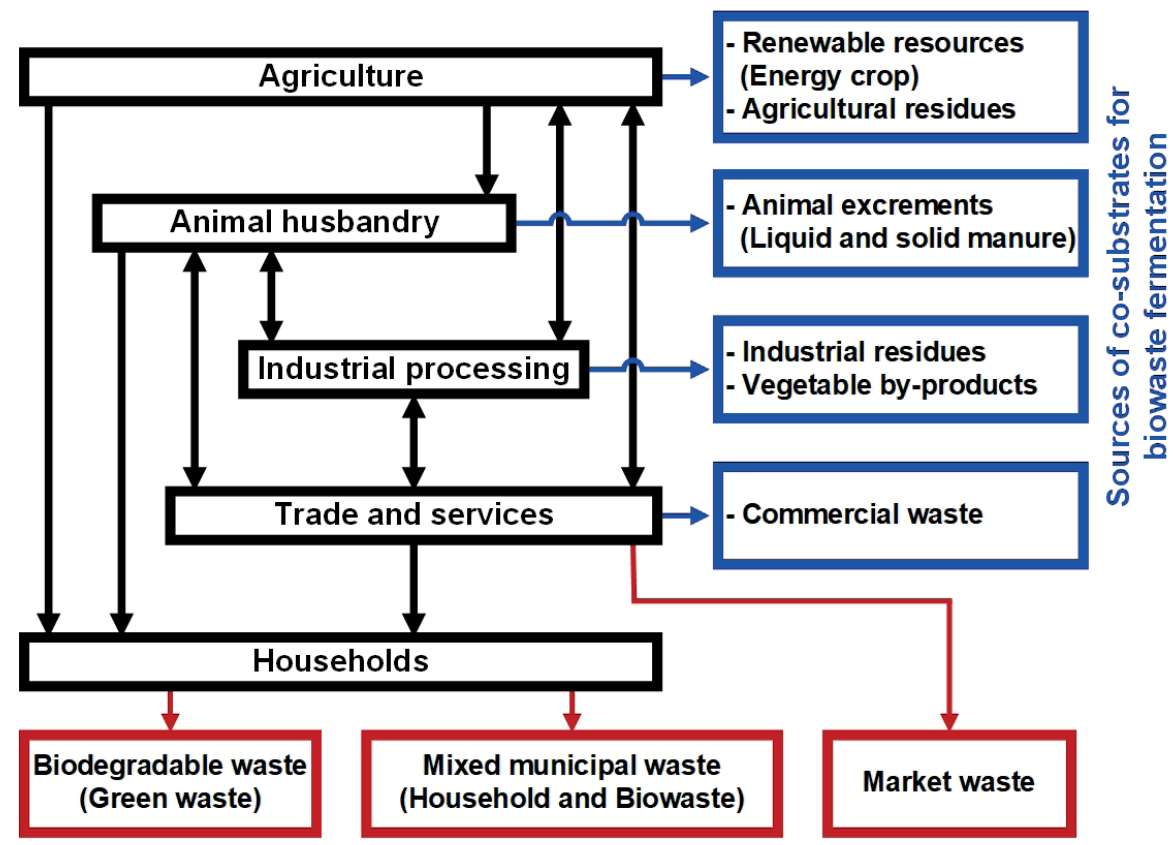

Main sources of feedstocks for biowaste fermentation

FIGURE 1: Relationships between the production sectors of suitable substrates.

\section{BIOWASTE AS A SEASONALLY INFLUEN- CED SUBSTRATE}

This section is divided into two parts. In subsection 2.1 the technical terms and the influencing factors of biowaste are explained. Subsection 2.2 clarifies the methodology of data collecting.

\subsection{Biowaste and influencing factors}

The definition of the term "biowaste" has not yet been standardised and varies according to its origin (Henssen, 2009). In European law, for example, biowaste is defined as:

... biodegradable garden and park waste, food and kitchen waste from households, restaurants, caterers and retail premises and comparable waste from food processing plants. (Europäisches Parlament und Rat, 2008)

On the other hand, for the specific case of Germany, there is another definition of biowaste according to the Bioabfallverordnung (Bio-waste Ordinance), which is as follows:

Waste of animal or vegetable origin or from fungal materials for processing which can be metabolized by microorganisms, soil-borne organisms or enzymes, including waste for processing with a high organic content of animal or vegetable origin or of fungal materials... (Bundesamt für Justiz, 1998)

As can be seen, in both definitions there is a vegetable component in the biowaste. This vegetable part in biowaste is affected by strong seasonal fluctuations, which significantly influence the quantity and quality of the biowaste. There are five main parameters that have been recognised and considered by experts and scientists: legal requirements, social factors, waste and substrate management, structural factors and weather conditions, as shown in Table 1.

From the data in Table 1, it can be seen that the influencing parameters are very diverse. For this reason, the biowaste composition is a conglomerate of all these various influencing parameters.

The three terms "biowaste", "green waste" and "co-substrate" that are used in this paper are defined as follows:

- "Biowaste" is a mixture of kitchen waste, plant residues and vegetable residues. More precisely, it can be defined as the type of waste which is derived from organic household waste, which is collected separately in organic-waste containers;

- "Green waste" is all vegetable waste (garden waste etc.) within the organic waste;

- "Co-substrate" is feedstocks that can be used in addition to the main substrate in the fermentation process. In the context of biowaste treatment, they originate from agriculture or are waste products and residues from agriculture, animal husbandry, trade and industrial processes.

From the beginning of spring until the end of autumn, organic waste is significantly influenced by green waste. When the influencing parameters are weighted, the seasonal influence and the structural factors are especially important for the quality and quantity of organic waste. A recent study has shown that green waste (garden waste) and biowaste with high proportions of food waste have different gas yields (Fricke et al., 2013). Biowaste with a high proportion of kitchen waste can produce up to 100 times more biogas than green waste. 
TABLE 1: Advanced composition of influencing factors for biowaste (based on Kranert, 2010).

\begin{tabular}{|c|c|c|}
\hline Influencing parameter & Examples & \\
\hline Legal requirements & $\begin{array}{l}\text { - Laws } \\
\text { - Regulations }\end{array}$ & - Municipal statutes \\
\hline Social factors & $\begin{array}{l}\text { - Standard of living } \\
\text { - Consumer behaviour } \\
\text { - Environmental awareness } \\
\text { - Sustainability awareness }\end{array}$ & $\begin{array}{l}\text { - Income } \\
\text { - Household sizes } \\
\text { - Tourism } \\
\text { - Education }\end{array}$ \\
\hline Waste and substrate management & $\begin{array}{l}\text { - } \text { Collection system } \\
\text { - } \text { Raste bin size } \\
\text { - } \text { Charging system }\end{array}$ & $\begin{array}{l}\text { Detection systems } \\
\text { - Public relations } \\
\text { - Waste prevention, deposition, treatment }\end{array}$ \\
\hline Structural factors & $\begin{array}{l}\text { - Building structure } \\
\text { - Sealing }\end{array}$ & $\begin{array}{l}\text { - Gardens, parks and plants } \\
\text { - Economic structure }\end{array}$ \\
\hline Weather conditions & $\begin{array}{l}\text { - Fair weather and frost periods } \\
\text { - Bad weather } \\
\text { - Clouds }\end{array}$ & $\begin{array}{l}\text { - Precipitation } \\
\text { - } \text { Air temperature and humidity } \\
\text { - Wind }\end{array}$ \\
\hline
\end{tabular}

The definitions "biogas yield" and "specific biogas yield" for the gaseous products from the anaerobic treatment of biowaste are defined in this paper as follows:

- "Biogas yield" $\left[\mathrm{I}_{\mathrm{BG}} /\right.$ Month $\left._{\mathrm{IN}}\right]$ is the volume of biogas in litres produced by the anaerobic digestion of biowaste by an average inhabitant per month.

- "Specific biogas yield" $\left[\mathrm{m}^{3}{ }_{\mathrm{BG}} / \mathrm{t}_{\mathrm{OS}}\right]$ is the specific yield of dry biogas in $\mathrm{m}^{3}$ under standard conditions which is produced from one tonne of biowaste as original substance.

\subsection{Methodology of data collection}

All data were collected on an existing biowaste treatment plant in Mecklenburg-Western Pomerania. The available data covered the period from January 2016 to December 2018. The generated data encompassed information on biowaste, green waste, temperature, fill level, gas contents for methane, carbon dioxide, oxygen and hydrogen sulphide, co-substrates, heat demand, and biogas production.

\section{DETERMINATION OF THE PROPORTION OF GREEN WASTE IN BIOWASTE}

Having evaluated the operating data of the biowaste fermentation plant (Figure 2), we can state that the specific biowaste amount per inhabitant in the investigated region is between $2.50 \mathrm{~kg}$ per month in the winter months and $9.07 \mathrm{~kg}$ per month in summer (with a maximum green waste content of $72 \%$ in the biowaste). The following conclusions can be drawn from the data in Figure 2:

- The average amount of biowaste is highest between April and November;

- The quantity fluctuation range is most affected by the seasonal influence and structural factors during the months of March and June to August.

The influence of green waste results in a decrease in the specific biogas yield of the biowaste as well as in extensive challenges for the management of a biowaste fermentation plant.

To check if the proportion of green waste in biowaste is the relevant factor for the quantity changes, a correla-

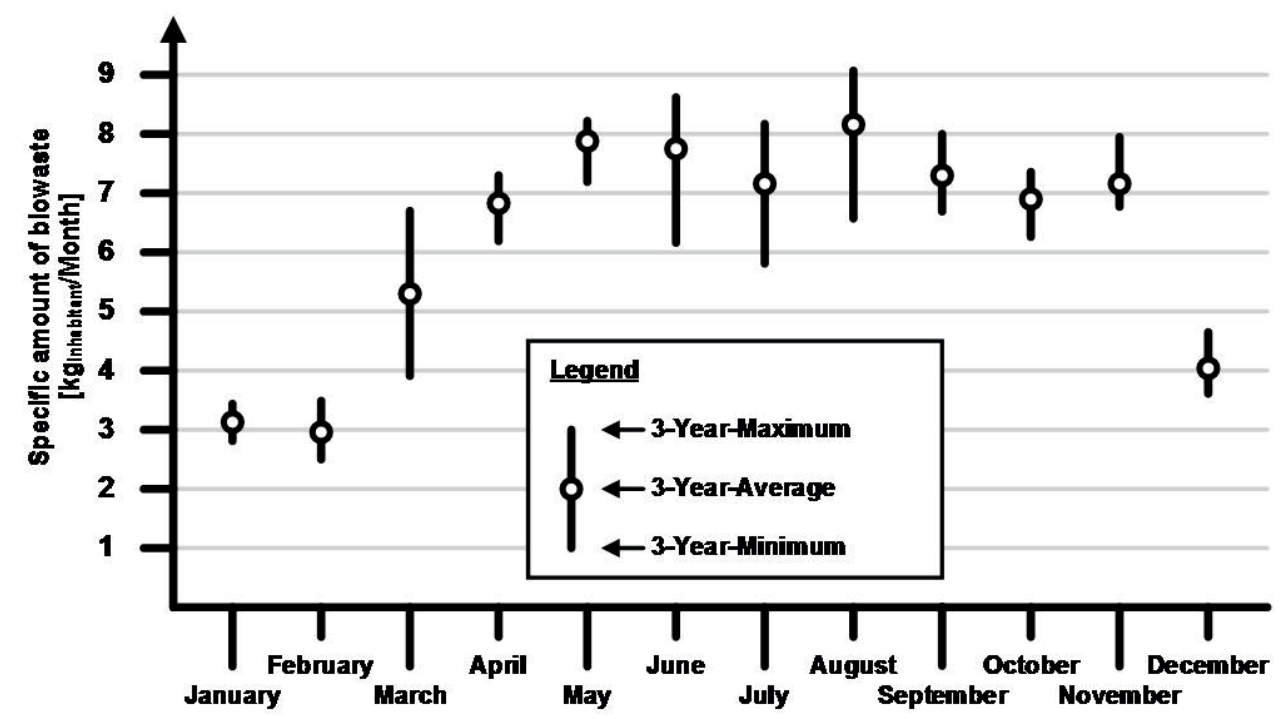

FIGURE 2: An exemplary presentation of the specific biowaste quantity of a biowaste fermentation plant in the annual cycle (2016 to 2018). 
tion analysis according to Pearson was performed. The analysis with separately recorded green waste and biowaste resulted in a correlation coefficient of 0.94 (very strong correlation).

The following assumptions were made to determine the proportion of green waste in biowaste of a geographically limited region:

- No or similar co-substrates are used in the fermentation process;

- The number of inhabitants must be known for the investigation period;

- Biowaste from other regions has similar substrate characteristics;

- The observation period is three years, calculated on a monthly basis.

The following formula (1) can be used to estimate the mass of green waste in biowaste. In this determination, the month with the lowest proportion of green waste in the organic material is determined and subtracted from the month under investigation.

$m_{G . i . B .(M / Y)}=m_{B(M / Y)}-m_{B \min (B W 01 / 2016 \text { to 12/2018) }}$

$m_{\text {G.i.B. }(\text { Month } / \text { Year })}=$ Mass of green waste in biowaste in the relevant month

$m_{B \text { (Month/Year) }}=$ Mass of biowaste in the relevant month $m_{B \min }$ (BW 01/2016 to 12/2018) $=$ Minimum amount of biowaste during the observation period

With the determined mass of green waste in biowaste, the weight proportion of green waste in the biowaste can be calculated by dividing it by the mass of biowaste in the month under investigation.

$w_{\text {G.i.B. }(\text { Month } / \text { Year })}=100 \times \frac{m_{\text {G.i.B. }(\text { Month } / \text { Year })}}{m_{B \text { (Month } / \text { Year })}}$

$w_{\text {G.i.B. }(\text { Month } / \text { Year })}=$ Weight proportion of green waste in the relevant month

$m_{\text {G.i.B.(Month } / \text { Year })}=$ Mass of green waste in the relevant month

$m_{B(\text { Month } / \text { Year })}=$ Mass of biowaste in the relevant month

After the monthly data for green waste and biowaste has been determined, the average percentage of green waste can be determined by summing the monthly relevant masses of green waste and dividing them by the sum of the monthly relevant masses of biowaste. The formula for determining the average proportion of green waste in biowaste (Formula 3) over the observation period (2016 to 2018) is as follows:

$$
\begin{aligned}
& W_{\text {G.i.B. }(M o n t h / 2016-18)}= \\
& =100 \times \frac{m_{G . i . B(x / 2016)}+m_{G . i . B(x / 2017)}+m_{G . i . B(x / 2018}}{m_{B(x / 2016)}+m_{B(x / 2017)}+m_{B(x / 2018)}}
\end{aligned}
$$

$w_{\text {G.i.B.(Month } / 2016-2018)}=$ Average weight proportion of green waste in the relevant month

$m_{\text {G.i.B. }(\text { Month } / \text { Year) }}=$ Mass of green waste in the relevant month

$m_{B}($ Month $/$ Year $)=$ Mass of biowaste in the relevant month $x=$ Relevant month
It can be seen from Figure 3 that the proportion of green waste massively influences the composition of the biowaste. Green waste is the dominant component of organic waste, especially in the months from April to November. For example, the average maximum proportion of green waste was in August (69\% green waste and 31\% food waste) and the average minimum content was in February ( $14 \%$ green waste and $86 \%$ food waste). It can be concluded that winter is the season with the maximum specific biogas yield. The specific biogas yield can be up to $100 \%$ higher for biowaste with a high content of kitchen waste compared to biowaste with a high content of green waste (Fricke et al., 2013).

\section{BIOGAS YIELD AS A FUNCTION OF THE PROPORTION OF GREEN WASTE}

A central issue that needs to be addressed in this context is establishing a relationship between specific biogas yield and the proportion of green waste in biowaste. The evaluation of the plant data shows that the specific biogas yield correlates with the proportion of green waste in the biogas (Figure 4). The calculation formula (4) for the specific biogas yield resulting from the practical values is a quadratic equation. The values for the coefficients $(a, b, c)$ were simplified, where $a$ is $-140 \mathrm{~m}^{3}{ }_{\mathrm{BG}} / \mathrm{t}_{\mathrm{OS}}, \mathrm{b}$ is $-5 \mathrm{~m}^{3}{ }_{\mathrm{BG}} / \mathrm{t}_{\mathrm{OS}}$ and $\mathrm{c}$ is $160 \mathrm{~m}^{3}{ }_{\mathrm{BG}} / \mathrm{t}_{\mathrm{OS}}$. The simplification of the calculation formula (5) is intended to increase the practicability of the method for the operating personnel.

$Y_{B G}=a \times x^{2}+b \times x+c$

$Y_{B G}=-140 \times w_{G . i . B .}{ }^{2}-5 \times w_{G . i . B .}+160$

$Y_{B G}=$ Specific biogas yield

$\mathrm{x}=w_{\text {G.i.B. }}$ (Month/2016-2018) $=$ Average weight proportion of green waste in the relevant month

The graph shows a slight decrease of the specific amount of biogas with increasing proportion of green waste in biowaste. In August 2017 a calculated share of $72 \%$ green waste in organic waste represents the maximum share of green waste in the observation period (three years).

To check the results of the calculation formula and to compare the practical data with the calculated values a descriptive data analysis was carried out (Table 2). The data are from March 2017 to February 2018. The results of the descriptive data analysis show that the calculated values for the specific biogas yield with the postulated methodology are comparable with the practical values of the examined plant. For instance the difference between the calculated and the plant values of mean specific biogas yield and $95 \%$ confidence interval of the mean in the investigation period is maximum $1.33 \mathrm{~m}^{3}{ }_{\mathrm{BG}} / \mathrm{t}_{\mathrm{OS}}$. Furthermore the median, minimum and maximum values are also comparable. In both analyses we find a distribution curve with a right skewness (depending on the positive value of the skewness). That indicates that the median value is lower than the mean value. The kurtosis of the practical values could be described as platykurtic, which means that the tails from the normal distribution are lighter. The tails ba- 


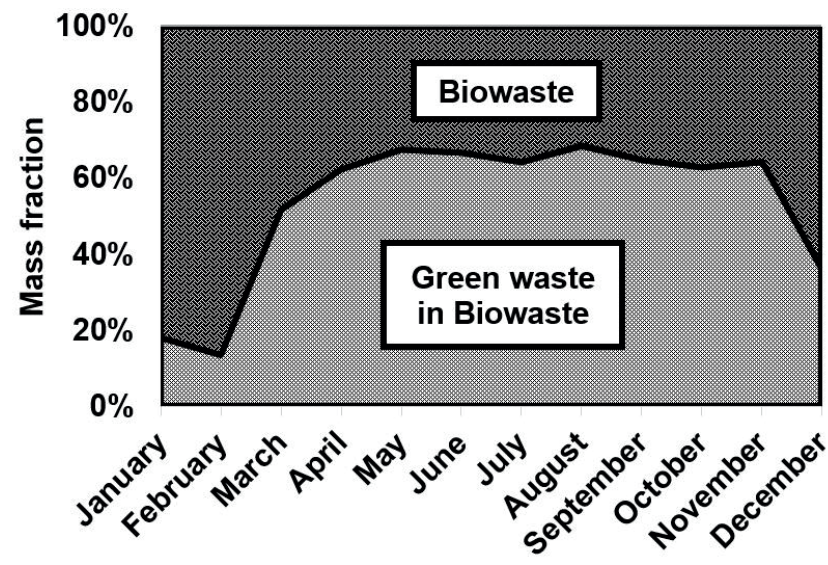

FIGURE 3: Calculated share of green waste in biowaste (2016 to 2018).

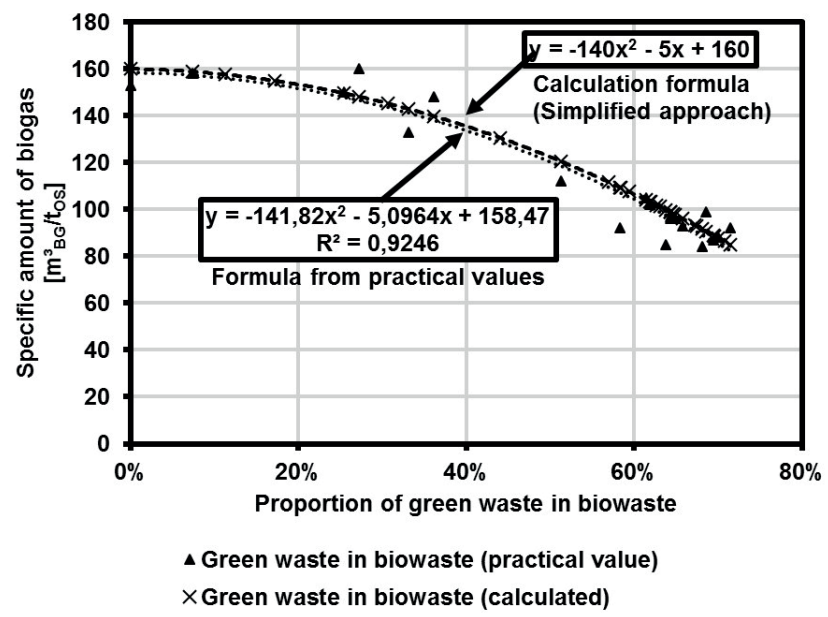

FIGURE 4: Specific biogas yield as a function of the proportion of green waste in biowaste (2016 to 2018)

sed on the data of the postulated calculation method are heavier and the curve is leptokurtic (Weaver, 2018).

The results of this research strongly support the assumption that the proportion of green waste in biowaste is the dominant influencing parameter of the specific biogas yield. Furthermore, the calculation method is suitable for and adaptable to other plants.

Figure 5 shows the regional characteristics of the studied region. As already mentioned, the specific biogas yield is strongly dependent on the proportion of green waste in biowaste. Although the substrate-specific biogas yield is lower in times with high vegetation rate, the biogas yield per inhabitant is higher due to the increasing proportion of green waste in biowaste. These key data could be used as a basis for the design of future fermentation plants.

When comparing the plant capacity and the achievable gas yield from biowaste over the year, only one possible variant with a maximum co-substrate input of $10 \%$ per day should be investigated because this variant represents the preferred variant for plant operation. If more than $10 \%$ co-substrates are used per year, the economic consequences for the operator would be negative because the feed-in tariff would decrease. The possibility of time-independent co-substrate use is not further discussed in this paper.

\section{LABORATORY RESULTS}

Batch tests are featured by one-time feeding of substrate and the logging of amount and quality of the biogas over the test period. Samples for the batch tests are characterised by urban and rural settlement structures and comes from the separate collection of biowaste in Schwerin (the regional capital of Mecklenburg-Western Pomerania). The test site at the University of Rostock is equipped with several batch-fermenters of 30 litres each. The tests are carried out at mesophilic temperatures $\left(37^{\circ} \mathrm{C}\right)$. Each sample is tested in a sixfold determination. The fermenter content is mixed by magnetic stirrers. The produced biogas is stored in special gas sampling bags which are deflated regularly. While deflating, the volume and composition of the produced biogas are measured. The volume is measured by a RITTER drum-type gas meter. For the representation of the results, the gas volume is converted to volume under normal conditions ( $273 \mathrm{~K}, 1013 \mathrm{hPa})$. For the measurement of the gas composition, an EHEIM gas analyser with sensors for $\mathrm{CH}_{4}, \mathrm{CO}_{2}, \mathrm{O}_{2}$ and $\mathrm{H}_{2} \mathrm{~S}$ is used. The biowaste sample per batch fermenter is about $600 \mathrm{~g}$ by using fermentation residue from a waste water treatment plant as inoculum. Due to the high sample mass of $600 \mathrm{~g}$ untreated heterogeneous biowaste, influences of conditioning which can cause losses of volatile substances, are excluded, as far as possible.

Batch tests were carried out according to the German directive VDI 4630 (VDI, 2016) for each season to support the thesis that seasonal fluctuations in urban and rural areas have different effects on biogas yield (Table 3 ).

The table clearly shows that the biogas yield from urban areas is more constant and higher. The average median value of rural biowaste is $109.79 \mathrm{~m}^{3}{ }_{\mathrm{BG}} / \mathrm{t}_{\mathrm{OS}}$ with a variance of 411 compared with urban biowaste with a median value of $134.51 \mathrm{~m}^{3}{ }_{\mathrm{BG}} / \mathrm{t}_{\mathrm{OS}}$ and a variance of 249 . A biogas yield between 27 and $168 \mathrm{~m}^{3}{ }_{\mathrm{BG}} / \mathrm{t}_{\mathrm{OS}}$ can be achieved with biowaste (ATV-DVWK, 2003).

During the winter months, as can be seen from Figure 2, the proportion of green waste in organic waste decreases. For this reason, biogas production is quite similar and the gas yield is almost the same for both substrates in this period. The increasing proportion of green waste can explain the fluctuation in rural biowaste.

The methane content of the biogas is very similar for both substrates. According to ATV-DVWK (2003) the average biogas yield is between 55 and $65 \mathrm{~m}^{3}{ }_{\mathrm{BG}} / \mathrm{t}_{\mathrm{OS}}$. The dry matter content varies between 34.3 and 49.7 , which is typical for biowaste.

After reaching the abort criteria (the daily increase of biogas volume is lower than $1 \%$ ) the batch test was stopped. The divergent specific biogas yield compared to the plant (92 versus $160 \mathrm{~m}^{3}{ }_{\mathrm{BG}} / \mathrm{t}_{\mathrm{OS}}$ ) can be explained by the residence time of 32 to 47 days in the batch test. 
TABLE 2: Descriptive data analyses of the biogas yield

\begin{tabular}{|c|c|c|c|c|c|}
\hline & & \multicolumn{2}{|c|}{ Plant values $\left[\mathrm{m}^{3}{ }_{\mathrm{BG}} / \mathrm{t}_{\mathrm{OS}}\right]$} & \multicolumn{2}{|c|}{ Calculated values $\left[\mathrm{m}^{3}{ }_{\mathrm{BG}} / \mathrm{t}_{\mathrm{OS}}\right]$} \\
\hline & & Statistic & Std. error & Statistic & Std. error \\
\hline \multicolumn{2}{|l|}{ Mean } & 109.22 & 7.23 & 110.36 & 7.33 \\
\hline \multirow{2}{*}{$\begin{array}{l}95 \% \text { Confidence interval } \\
\text { for mean }\end{array}$} & Lower bound & 93.30 & & 94.23 & \\
\hline & Upper bound & 125.15 & & 126.48 & \\
\hline \multicolumn{2}{|l|}{$5 \%$ trimmed mean } & 107.59 & & 109.02 & \\
\hline \multicolumn{2}{|l|}{ Median } & 98.12 & & 101.05 & \\
\hline \multicolumn{2}{|l|}{ Variance } & 628.11 & & 644.18 & \\
\hline \multicolumn{2}{|l|}{ Std. deviation } & 25.06 & & 25.38 & \\
\hline \multicolumn{2}{|l|}{ Minimum } & 87.98 & & 84.84 & \\
\hline \multicolumn{2}{|l|}{ Maximum } & 159.91 & & 160.00 & \\
\hline \multicolumn{2}{|l|}{ Range } & 71.93 & & 75.16 & \\
\hline \multicolumn{2}{|l|}{ Interquartile range } & 34.66 & & 42.48 & \\
\hline \multicolumn{2}{|l|}{ Skewness } & 1.37 & 0.64 & 1.13 & 0.64 \\
\hline \multicolumn{2}{|l|}{ Kurtosis } & 0.43 & 1.23 & -0.17 & 1.23 \\
\hline
\end{tabular}

\section{CONCLUSIONS}

Statements about the influence of green waste in biowaste on the specific biogas yield are possible. The presented method provides a regional analysis of biowaste flows and an estimation of the expected specific biogas yield. In comparison to previously used guideline values, this me- thod allows better planning of new biowaste fermentation plants. Based on these results, the use of co-substances in existing plants can be optimised and the baseload capacity of the fermentation plant can be increased.

Furthermore, there are several variants to reduce the proportion of green waste in biowaste. For example, mechanical treatment (sieving, sorting) and the separate col-

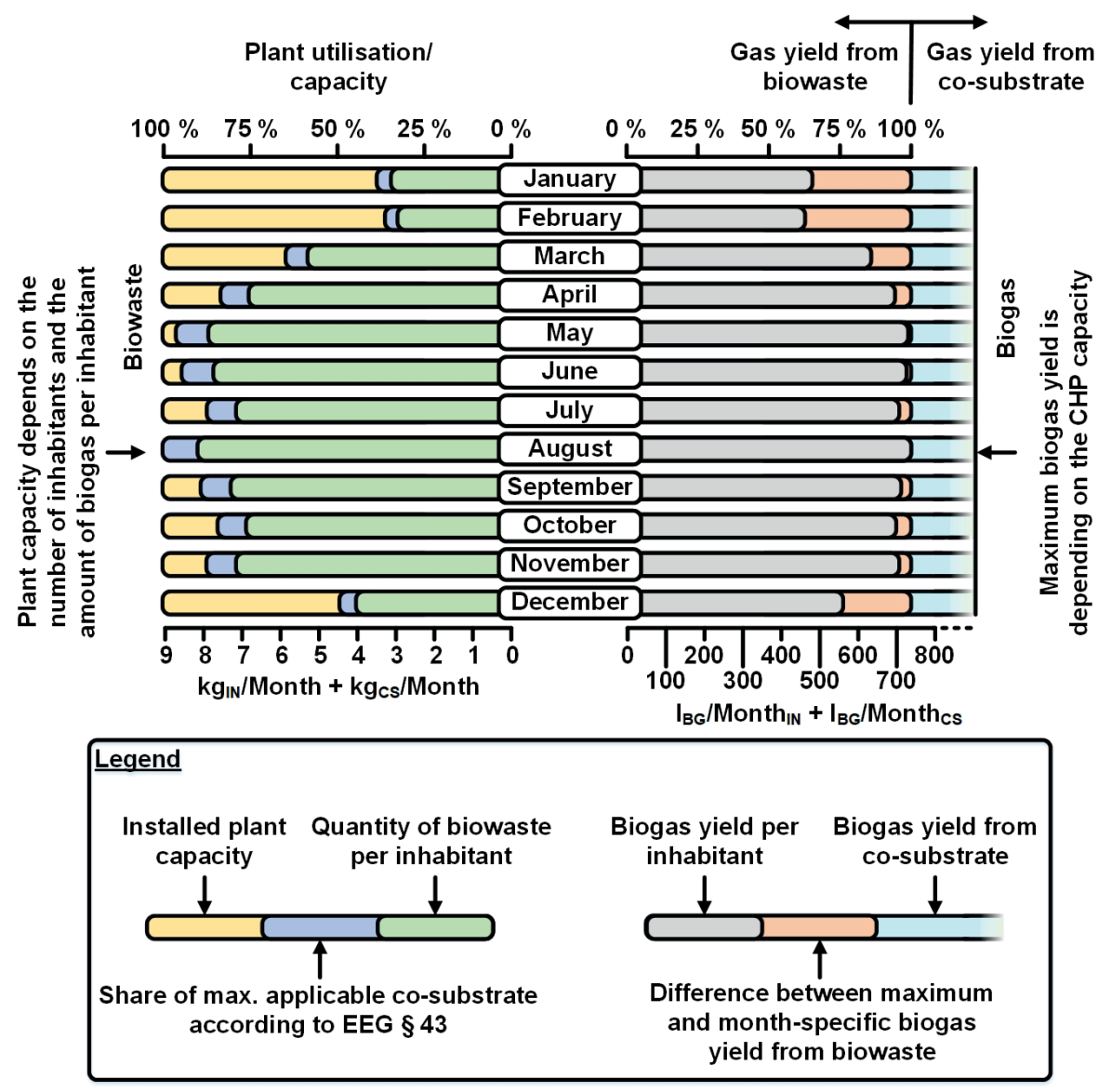

FIGURE 5: Comparison of plant capacity and gas yield of a biowaste fermentation plant (regional specific parameters). 
TABLE 3: Median values for biogas yield, dry matter and methane content of urban and rural biowaste.

\begin{tabular}{|c|c|c|c|c|}
\hline Season & Region & $\begin{array}{l}\text { Dry matter of } \\
\text { biowaste [\%] }\end{array}$ & $\begin{array}{c}\text { Biogas yield } \\
{\left[\mathrm{m}^{3}{ }_{\mathrm{BG}} / \mathrm{t}_{\mathrm{OS}}\right]}\end{array}$ & $\begin{array}{l}\text { Methane con } \\
\text { tent [Vol.-\%] }\end{array}$ \\
\hline \multirow{2}{*}{ Winter } & Urban & 34.9 & 137.56 & 59.03 \\
\hline & Rural & 34.3 & 138.00 & 59.99 \\
\hline \multirow{2}{*}{ Spring } & Urban & 35.6 & 123.94 & 63.77 \\
\hline & Rural & 47.8 & 107.80 & 57.48 \\
\hline \multirow{2}{*}{ Summer } & Urban & 43.5 & 136.07 & 62.96 \\
\hline & Rural & 49.7 & 100.05 & 57.69 \\
\hline \multirow{2}{*}{ Autumn } & Urban & 40.7 & 135.55 & 57.64 \\
\hline & Rural & 36.3 & 113.66 & 56.03 \\
\hline
\end{tabular}

lection of green waste are conceivable. The aim of these ideas is to increase the specific biogas yield and to reduce the impact of green waste on the quantity and quality of biowaste. Benefits are efficient biogas production and constant reaction conditions. Furthermore, the microorganisms in the fermenter have a higher security against process disturbances. Moreover, with these methods, the use of co-substrate can be optimised and the efficiency of the whole process setup increase.

However, the chosen method has several limitations. Firstly, the retention time in the fermenter is assumed to be constant. Especially in the winter months, the residence time increases with decreasing quantity of biowaste. Secondly, the region-specific evaluation results from a specific mix of rural and urban biowaste. In other regions the evaluation would be different. The method refers only to dry fermentation of biowaste under thermophilic temperature conditions. In order to make statements about the influence of co-substrates on the process, further investigations are necessary.

\section{ACKNOWLEDGEMENTS}

The presented work is part of the running research project "Network Stability with Wind and Bioenergy, Storage and Loads (Netz-Stabil)". The authors are grateful to the Excellence Initiative of the Federal State MecklenburgWestern Pomerania funded by the European Social Fund for Germany (ESF/14-BM-A55-0021/16) for support of the research.

\section{REFERENCES}

ATV-DVWK (2003). ERGÄNZUNGSBLATT Merkblatt ATV-DVWK-M 372 Technische Rahmenbedingungen für die Vergärung von Abfällen. Hennef: Ges. zur Förderung der Abwassertechnik e.V. (Translation: Technical framework conditions for the fermentation of wastes).
Bundesamt für Justiz (1993). TA Siedlungsabfall: Technische Anleitung zur Verwertung, Behandlung und sonstigen Entsorgung von Siedlungsabfällen (Translation: Technical directive on the recovery, treatment and other disposal of municipal waste) (Dritte Allgemeine Verwaltungsvorschrift zum Abfallgesetz) vom 14. Mai 1993 (BAnz. Nr. 99a vom 29.05.1993).

Bundesamt für Justiz (1998). Verordnung über die Verwertung von Bioabfällen auf landwirtschaftlich, forstwirtschaftlich und gärtnerisch genutzten Böden: Bioabfallverordnung - BioAbfV. (Translation: Ordinance on the Recovery of Bio-Waste on Land used for Agricultural, Silvicultural and Horticultural Purposes (Bio-waste Ordinance - BioAbfV).Retrieved from https://www.gesetze-im-internet.de/ bioabfv/BioAbfV.pdf (accessed 28.05.2019).

Bundesamt für Justiz (2012). Gesetz zur Förderung der Kreislaufwirtschaft und Sicherung der umweltverträglichen Bewirtschaftung von Abfällen: Kreislaufwirtschaftsgesetz - KrWG. (Translation: Act to Promote Circular Economy and Safeguard the Environmentally Compatible Management of Waste: Closed Cycle Management Act).Retrieved from https://www.gesetze-im-internet.de/krwg/ KrWG.pdf (accessed 28.05.2019).

Bundesamt für Justiz (2014). Gesetz für den Ausbau erneuerbarer Energien (Erneuerbare-Energien-Gesetz - EEG 2017): EEG 2017. (Translation: Act for the development of renewable energies (Renewable Energy Sources Act - EEG 2017)). Retrieved from https:// www.gesetze-im-internet.de/eeg_2014/EEG_2017.pdf (accessed 28.05. 2019).

Europäisches Parlament und Rat (2008). Richtlinie 2008/98/EG des europäischen Parlamente und des Rates: vom 19. November 2008 über Abfälle und zur Aufhebung bestimmter Richtlinien (Text von Bedeutung für den EWR) (ABI. L 312 vom 22.11.2008, S. 3). (Translation: Directive 2008/98/EC of the European Parliament and of the Council of 19 November 2008 on waste and repealing certain Directives (Text with EEA relevance)). Retrieved from https://eurlex.europa.eu/legal-content/DE/ALL/?uri=CELEX\%3A32008L0098 (accessed 28.05.2019).

Henssen, D. (2009). Einführung und Optimierung der getrennten Sammlung zur Nutzbarmachung von Bioabfällen. (Translation: Introduction and optimisation of separate collection for the utilisation of biowaste) Retrieved from https://www.vhe.de/fileadmin/ vhe/pdfs/Publikationen/Veroeffentlichungen/Bioabfall_Handbuch_VHE.pdf (accessed 28.05.2019).

Fricke, K., Heußner, C., Hüttner, A., Turk, T., Bauer, W., \& Bidlingmaier, W. (2013). Vergärung von Biound Grünabfällen: Teil 1: Ausbaupotenzial bei der Vergärung von Bio- und Grünabfällen (Translation: Anaerobic digestion of biowaste Part 1: Potential for expansion in the fermentation of biowaste) Müll und Abfall. (12), 628-635.

Kranert, M. (Ed.) (2010). Studium. Einführung in die Abfallwirtschaft: Mit 131 Tabellen [mit Online-Service] (Translation: Introduction to waste management) (4., vollst. aktualisierte und erw. Aufl.). Wiesbaden: Vieweg + Teubner. Statistisches Bundesamt (2019). (Translation: Federal Statistical Office) Abfallentsorgung - Fachserie 19 Reihe 1 - 2016. Retrieved from https://www. destatis.de/DE/Themen/Gesellschaft-Umwelt/Umwelt/Abfallwirtschaft/Publikationen/Downloads-Abfallwirtschaft/abfallentsorgung-2190100167004.pdf?_blob=publicationFile\&v=4 (accessed 28.05.2019).

VDI (2016). Vergärung organischer Stoffe: Substratcharakterisierung, Probenahme, Stoffdatenerhebung, Gärversuche (Translation: Fermentation of organic materials: substrate characterisation, sampling, collection of material data, fermentation experiments) (Ausg. deutsch/englisch). VDI-Handbuch Technik Biomasse/Boden: VDI 4630. Berlin: Beuth Verlag GmbH.

Weaver, K. F. (2018). An introduction to statistical analysis in research: With applications in the biological and life sciences. Hoboken $\mathrm{NJ}$ : Wiley. 